JAPANESE POLITICAL SCIENCE REVIEW 3 (2016), 15-28 (DOI: 10.15545/3.15)

(C) 2016 Japanese Political Science Association

\title{
NATORI RYOTA
}

\section{Does a Mixed-Member Majoritarian System Lead to a Party Vote? The Decision of Japanese Voters \\ in the 2012 and 2014 General Elections}

One of the aims of the reform of the electoral system in 1994 was to increase the party vote. While the old system of multi-member districts with a single non-transferable vote promoted intra-party competition, the new system would encourage inter-party competition. The reformers expected Japanese electoral politics to become a party-oriented election. The analysis in this paper, however, shows that Japanese voters preferred a personal vote to a party vote in the 2012 general election. The results of a logistic regression analysis showed that the supporters of the Democratic Party of Japan and voters in districts where two parties competed tended toward the personal vote. The suggestion here is whether the voters who cast a personal vote are determined by not only the effect of the electoral system but also the evaluation of parties.

KEYWORDS: mixed-member majoritarian, personal vote, party vote, electoral reform

NATORI Ryota is a Professor at Kansai University. His research interests lie in electoral systems and local politics. This paper is a revised and expanded version of a paper entitled "Reversion to the Candidate Centered Election in the Japanese Lower House Election," presented at the 2014 Conference of Asian Electoral Studies (Seoul, Korea, 18 October 2014), and a paper entitled "2012 nen shugiin senkyo ni okeru seitō tōhyō to kōhosha tōhyō" (Party and personal voting in the 2012 Japanese Lower House election), Joho Kenkyū 41: 71-84. This work was supported by a JSPS Grant-in-Aid for Specially Promoted Research (Grant Number: 24000002). 
ONE OF THE AIMS of the introduction of the mixed-member majoritarian (MMM) system in Japan was to change from candidate-centered elections to party-centered elections.

As the system of multi-member districts with a single non-transferable vote (SNTV) promotes intra-party competition, the incentives for personal votes are increased. Thus, election campaigning by candidates themselves was effective. Under the MMM system, in turn, inter-party competition is promoted, and because party policies become more influential factors, the effectiveness of election campaigning by candidates themselves is decreased. Thus, many reformers expected to create a partycentered election due to the introduction of the MMM system.

Nevertheless, recent research has shown that voters have changed, but election campaigns by parties and candidates have not. Taniguchi observed that the connection between political parties and their supporting organizations has become weaker, and a party's ability to mobilize voters has decreased (TANIGUCHI 2004). Niwa showed that the reduction of the number of local assembly members due to the amalgamation of municipalities has weakened the local organization of the Liberal Democratic Party (LDP), and they have become unable to mobilize voters (NIwA 2010). Hirano has pointed out that there has been an increase in party votes based on the evaluation of the party leader and the evaluation of his or her performance. There has also been a decrease in the personal vote (Намамото 2007; Hirano 2008).

On the other hand, several authors have suggested that election campaigns by political parties and candidates continued to be centered on the candidates even after the introduction of the MMM system (YamadA 1997; Park 2000; Krauss and Pekkanen 2004; Taniguchi 2004). It has also been observed that LDP members have increased their election campaigns in electoral districts (Намамото and Nемото 2011). As Shinada has stated, Japanese voters have shifted to a party vote, while political parties and candidates have continued election campaigns centered on candidates since the introduction of the MMM system (SHINADA 2011).

However, voting behavior in the 2012 general election was different than it had been up to that point. As noted in the next section, the personal vote increased: $18.3 \%$ of voters (a $2.6 \%$ increase compared with 2009) stated that it was the candidate's personality that was the deciding factor for voting in single-member districts, and $7.3 \%$ (an increase of $1.7 \%$ compared with 2009) answered that it was the candidates' policies that were the decisive factor. Personal votes increased by a total of $4.3 \%$. Conversely, only $29.8 \%$ of voters (a 13.7\% reduction) selected party support. 
It is possible to perceive this change as something that came about accidentally in the 2012 general election. However, this paper claims that this is not the case. The MMM system does not lead to a party vote and party-centered elections. Under the MMM system, whether or not a party vote is made depends on how political parties are evaluated. The electoral system regulates the structure of inter-party competition, but it can either promote the party vote or not promote it depending on how the political party is evaluated.

This claim will be examined below through an analysis of data from a survey that was conducted after the general election of 2012. ${ }^{1}$

\section{Electoral Competition and \\ Voting Behavior in the 2012 Japanese General Election}

One feature of the 2012 general election was the increase in political parties that participated. There were six political parties that ran more than 50 candidates in single-member districts (SMD). This was the greatest number of political parties since the 1996 general election. The effective number of candidates had decreased until the 2009 general election, but in the 2012 general election the average increased (2.97). This marked a return to the level of the 1996 general election (2.95). TABLE 1 shows the pattern of party competition at the district level. ${ }^{2}$ There were 12 electoral districts (4.0\%) that had candidates from five political parties; $23.0 \%$ of electoral districts had four political parties running a candidate; districts where three parties were competing were the most numerous at $42.7 \%$; and twoparty competition occurred in $22.3 \%$ of 300 districts.

In this electoral environment, how did Japanese voters decide who to vote for in SMD? Our survey included a question asking what factors were decisive for respondents in SMD in deciding who to vote for. We measured the party vote and the personal vote using this question.

Thus, a vote is a party vote if the respondent chooses party support, party policies, or the evaluation of a party leader as a deciding factor, and

1. The survey from which the data are used in this paper was conducted by CGCSGCOE. This survey was conducted using face-to-face interviews after the general election from 5 January 2013 to 24 January 2013 . The response rate was $79.70 \%$ (1,437 responses).

2. Electoral districts were counted, limiting the political parties to the LDP, the Democratic Party of Japan (DPJ), the Your Party (Minna), the Japan Restoration Party (Ishin), and the Tomorrow Party of Japan (Mirai). In actuality, there was a further increase in the number of candidates because the Japan Communist Party (JCP) and influential independents ran candidates in SMD. 


\begin{tabular}{|c|c|c|c|}
\hline NUMBER OF & PATTERN OF & NUMBER OF & \\
\hline PARTIES & COMPETITION $^{*}$ & DISTRICTS & $\%$ \\
\hline Five & $\begin{array}{l}\text { LDP vs DPJ vs Minna vs Ishin } \\
\text { vs Mirai }\end{array}$ & 12 & 4.0 \\
\hline \multirow[t]{3}{*}{ Four } & LDP vs DPJ vs Minna vs Ishin & 16 & 5.3 \\
\hline & LDP vs DPJ vs Ishin vs Mirai & 42 & 14.0 \\
\hline & LDP vs DPJ vs Minna vs Mirai & 11 & 3.7 \\
\hline \multirow[t]{4}{*}{ Three } & LDP vs DPJ vs Ishin & 66 & 22.0 \\
\hline & LDP vs DPJ vs Minna & 23 & 7.7 \\
\hline & LDP vs DPJ vs Mirai & 34 & 11.3 \\
\hline & LDP vs Ishin vs Mirai & 5 & 1.7 \\
\hline \multirow[t]{3}{*}{ Two } & LDP vs DPJ & 52 & 17.3 \\
\hline & LDP vs Ishin or Mirai or Minna & 15 & 5.0 \\
\hline & Others & 24 & 8.0 \\
\hline TOTAL & & 300 & 100.0 \\
\hline
\end{tabular}

TABLE 1. Patterns of party competition at the district level.

* Apart from JCP candidates and influencial independents.

\begin{tabular}{lcccc}
\hline & \multicolumn{3}{c}{$(\%)$} & 2012 \\
\hline Evaluation of party leaders & 2003 & 2005 & 2009 & 6.3 \\
Party support & 6.4 & 13.1 & 3.8 & 29.8 \\
Party policy & 31.8 & 34.6 & 43.5 & 12.1 \\
\hline Party vote total & 8.7 & 7.6 & 11.5 & 48.2 \\
\hline Candidate personality & 46.9 & 55.3 & 58.8 & 18.3 \\
Candidate policy & 20.2 & 15.2 & 15.7 & 7.3 \\
\hline Personal vote total & 5.1 & 5.0 & 5.6 & 25.6 \\
\hline Balance of seats & 25.3 & 20.2 & 21.3 & 4.0 \\
Profitability of the work- & 5.4 & 4.9 & 3.6 & 1.1 \\
place & 1.1 & 1.2 & 1.2 & 6.4 \\
Local interest & & & 7.2 & 4.1 \\
Mobilization & 8.9 & 6.9 & 2.9 & 10.6 \\
Others & 3.9 & 3.9 & 5.0 & \\
\hline
\end{tabular}

TABLE 2. The transition of the decision factors in SMD.

Note: Cited in Hirano and KoHno (2011, page 216). 
it is a personal vote if the respondent chooses the candidate's personality or the candidate's policies.

TABLE 2 shows the transition in decision factors in single-member districts since the 2003 general election. As is clearly shown in the table, from 2003 the party vote increased, but decreased in 2012 . Conversely, there was an increase in the personal vote. The party vote comprised a total of $48.2 \%$, and the personal vote $25.6 \%$. This was at around the same level as in the 2003 election, where these percentages were $46.9 \%$ and $25.3 \%$ respectively.

Both of the features demonstrate the opposite of the results that were expected to be brought about by the MMM system. First, it was expected that the MMM system would lead to having two effective candidates, but in the 2012 election the effective number of candidates reverted to three. Second, it was expected that the MMM system would promote inter-party competition and reduce the personal vote, but in actuality, the importance of the personal vote increased.

\section{Party Support and the Personal Vote}

TABLE 3 shows a cross-tabulation of decision factors in SMD and the political party that the respondents voted for. The analysis here focuses on parties running a candidate in over fifty electoral districts.

\begin{tabular}{|c|c|c|c|c|c|c|c|}
\hline & \multicolumn{7}{|c|}{ PARTY VOTED FOR } \\
\hline & LDP & DPJ & MINNA & MIRAI & ISHIN & JCP & TOTAL \\
\hline Evaluation of party leaders & $7.5 \%$ & $5.3 \%$ & $9.8 \%$ & $0.0 \%$ & $8.2 \%$ & $1.8 \%$ & $6.3 \%$ \\
\hline Party support & $39.0 \%$ & $17.1 \%$ & $19.7 \%$ & $15.0 \%$ & $45.9 \%$ & $21.8 \%$ & $29.8 \%$ \\
\hline Party policy & $8.4 \%$ & $6.5 \%$ & $29.5 \%$ & $25.0 \%$ & $21.4 \%$ & $27.3 \%$ & $12.1 \%$ \\
\hline Party vote total & $54.9 \%$ & $29.0 \%$ & $59.0 \%$ & $40.0 \%$ & $75.5 \%$ & $50.9 \%$ & $48.2 \%$ \\
\hline Candidate personality & $15.5 \%$ & $33.9 \%$ & $11.5 \%$ & $20.0 \%$ & $6.1 \%$ & $9.1 \%$ & $18.3 \%$ \\
\hline Candidate policy & $5.1 \%$ & $8.6 \%$ & $8.2 \%$ & $10.0 \%$ & $4.1 \%$ & $10.9 \%$ & $7.3 \%$ \\
\hline Personal vote total & $20.6 \%$ & $42.4 \%$ & $19.7 \%$ & $30.0 \%$ & $10.2 \%$ & $20.0 \%$ & $25.6 \%$ \\
\hline Balance of seats & $.9 \%$ & $10.2 \%$ & $3.3 \%$ & $5.0 \%$ & $3.1 \%$ & $10.9 \%$ & $4.0 \%$ \\
\hline $\begin{array}{l}\text { Profitability of the } \\
\text { workplace }\end{array}$ & $.7 \%$ & $2.4 \%$ & $0.0 \%$ & $2.5 \%$ & $0.0 \%$ & $1.8 \%$ & $1.1 \%$ \\
\hline Local interest & $7.5 \%$ & $6.1 \%$ & $1.6 \%$ & $15.0 \%$ & $6.1 \%$ & $0.0 \%$ & $6.4 \%$ \\
\hline Mobilization & $4.9 \%$ & $3.3 \%$ & $0.0 \%$ & $2.5 \%$ & $1.0 \%$ & $7.3 \%$ & $4.1 \%$ \\
\hline Others & $10.5 \%$ & $6.5 \%$ & $16.4 \%$ & $5.0 \%$ & $4.1 \%$ & $9.1 \%$ & $10.5 \%$ \\
\hline $\mathrm{N}$ & 534 & 245 & 61 & 40 & 98 & 55 & 1138 \\
\hline
\end{tabular}

TABLE 3. Decision factors and party voted for. 


\begin{tabular}{|c|c|c|c|c|c|c|c|}
\hline & \multicolumn{7}{|c|}{ PARTY VOTED FOR } \\
\hline & LDP & DPJ & MINNA & MIRAI & ISHIN & $\mathrm{JCP}$ & TOTAL \\
\hline Evaluation of party leaders & $7.5 \%$ & $5.3 \%$ & $9.8 \%$ & $0.0 \%$ & $8.2 \%$ & $1.8 \%$ & $6.3 \%$ \\
\hline Party support & $39.0 \%$ & $17.1 \%$ & $19.7 \%$ & $15.0 \%$ & $45.9 \%$ & $21.8 \%$ & $29.8 \%$ \\
\hline Party policy & $8.4 \%$ & $6.5 \%$ & $29.5 \%$ & $25.0 \%$ & $21.4 \%$ & $27.3 \%$ & $12.1 \%$ \\
\hline Party vote total & $54.9 \%$ & $29.0 \%$ & $59.0 \%$ & $40.0 \%$ & $75.5 \%$ & $50.9 \%$ & $48.2 \%$ \\
\hline Candidate personality & $15.5 \%$ & $33.9 \%$ & $11.5 \%$ & $20.0 \%$ & $6.1 \%$ & $9.1 \%$ & $18.3 \%$ \\
\hline Candidate policy & $5.1 \%$ & $8.6 \%$ & $8.2 \%$ & $10.0 \%$ & $4.1 \%$ & $10.9 \%$ & $7.3 \%$ \\
\hline Personal vote total & $20.6 \%$ & $42.4 \%$ & $19.7 \%$ & $30.0 \%$ & $10.2 \%$ & $20.0 \%$ & $25.6 \%$ \\
\hline Balance of seats & $.9 \%$ & $10.2 \%$ & $3.3 \%$ & $5.0 \%$ & $3.1 \%$ & $10.9 \%$ & $4.0 \%$ \\
\hline $\begin{array}{l}\text { Profitability of the } \\
\text { workplace }\end{array}$ & $.7 \%$ & $2.4 \%$ & $0.0 \%$ & $2.5 \%$ & $0.0 \%$ & $1.8 \%$ & $1.1 \%$ \\
\hline Local interest & $7.5 \%$ & $6.1 \%$ & $1.6 \%$ & $15.0 \%$ & $6.1 \%$ & $0.0 \%$ & $6.4 \%$ \\
\hline Mobilization & $4.9 \%$ & $3 \cdot 3 \%$ & $0.0 \%$ & $2.5 \%$ & $1.0 \%$ & $7 \cdot 3 \%$ & $4.1 \%$ \\
\hline Others & $10.5 \%$ & $6.5 \%$ & $16.4 \%$ & $5.0 \%$ & $4.1 \%$ & $9.1 \%$ & $10.5 \%$ \\
\hline $\mathrm{N}$ & 534 & 245 & 61 & 40 & 98 & 55 & 1138 \\
\hline
\end{tabular}

TABLE 4. Decision factors and party voted for.

There is a difference in the percentages for each party. In descending order from the highest percentage, Ishin (75.5\%), Minna (59.0\%), the LDP $(54.9 \%)$, and the JCP $(50.9 \%)$ received a higher percentage of the party vote. Only the DPJ obtained more personal votes (42.5\%) than party votes (29.0\%). Focusing on each decision factor, with regard to the evaluation of party leaders, the three highest were Minna, Ishin, and the LDP, and the two lowest in this order were the JCP and Mirai. With regard to party support, Ishin and the LDP scored highly, with the DJP and Mirai low. New parties such as Minna, Mirai, and Ishin had a higher percentage of party policies as deciding factors, and the LDP and the DPJ had lower percentages. On the other hand, the DPJ had the highest rate of personal votes, followed in order by Mirai, the LDP, and the JCP.

Based on the above findings, an important factor for the increase in personal votes in the 2012 general election was identified by the relatively small amount of party votes for the DPJ. In the 2009 election, $73.5 \%$ of voters who voted for the DPJ answered that the decisive factor was the party vote, and $15.4 \%$ answered the personal vote. The impact of this change is great.

TABLE 4 is a cross-tabulation of decision factors and party support. The high percentage of personal votes by DPJ supporters stands out here as well. Party votes and the personal votes of unaffiliated voters were in competition. 
One peculiarity was that $17.8 \%$ of LDP supporters expressed the candidate's personality to be the most important decision factor. This is a relatively higher rate than the supporters of any other party except the DPJ and unaffiliated voters. Another feature is that the supporters of the JCP, Mirai, and Minna choose their party's policies as the most important factor. New parties, aside from Ishin, obtained votes based on the support of their policies rather than party support.

\section{Party Votes and the Environment of Party Competition}

Analyzing the 1996 general election, Miyake (2001) argued that party votes increased in electoral districts with two-party competition or in districts with an incumbent and a challenger. Thus, this argument was looked at also using data from the 2012 general election.

TABLE 5 shows the decision factors and the pattern of party competition. The highest rate of party votes is in districts where the LDP, the DPJ, Minna, and Ishin were competing (60.9\%). Conversely, districts where two political parties were competing, such as the LDP versus Mirai or the LDP versus the DPJ, got around $40 \%$ of party votes. Although the percentage of personal votes was higher in electoral districts where two parties were competing, districts where the number of competing political parties was large resulted in a high rate of party votes.

TABLE 6 shows party votes and candidate status. Almost no difference was seen when comparing the percentage of party votes. Personal votes were greatest when an incumbent was facing a challenger, and were the least when it was one new candidate against another. There was a higher rate of personal votes when an incumbent was facing another incumbent compared with when a new candidate was facing another new candidate. As seen above, the relationship in the 1996 election between the environment of electoral competition and party votes was not really observed in the 2012 election. Districts with two-party competition had high percentages of the personal vote. This is the opposite of the tendency that was seen in 1996. Furthermore, the difference in competition patterns regarding the status of the candidate did not influence the difference in the rate of the party vote. The overall difference was fairly small.

\section{Analysis}

In this section, I show the result of the multivariate analysis. The model is estimated by logistic regression analysis. In this analysis, the dependent variable was whether or not there was a party vote, using 1 if the decisive 


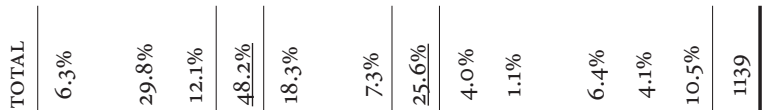

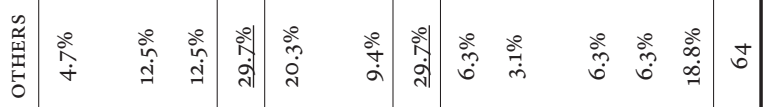

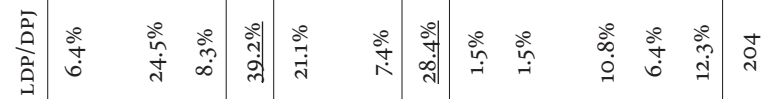

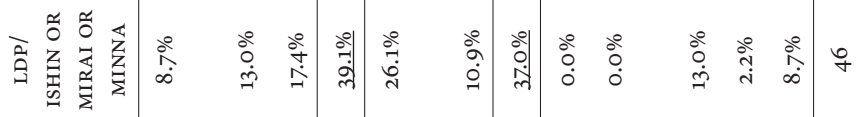

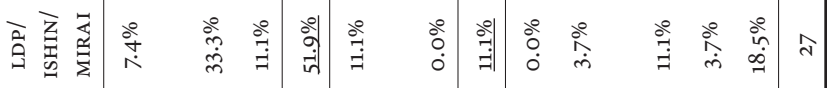

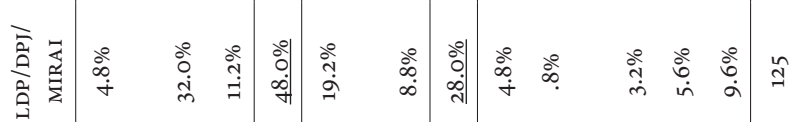

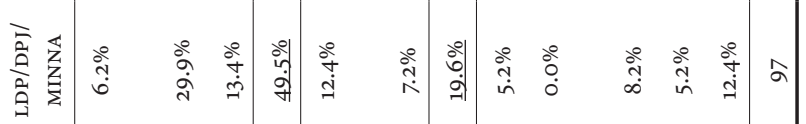

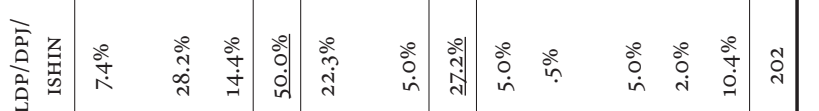

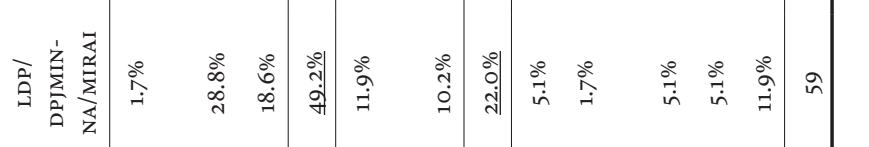

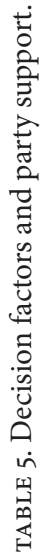

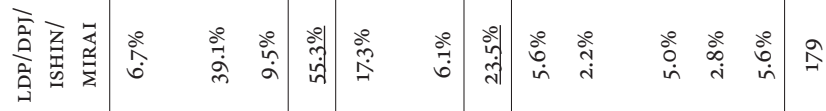

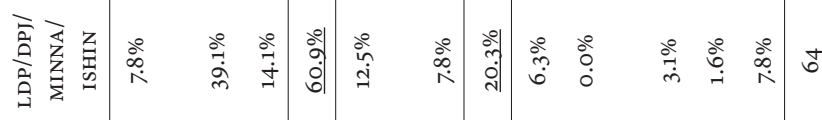

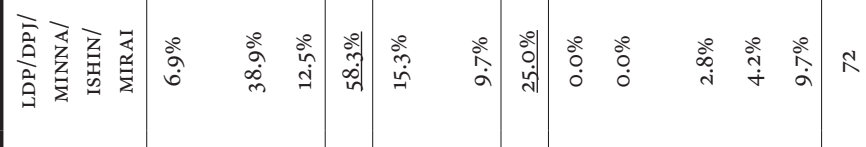

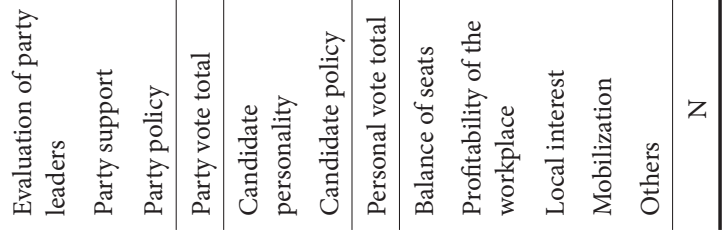




\begin{tabular}{|c|c|c|c|c|c|}
\hline & $\begin{array}{c}\text { NEW CHALLENGER } \\
\text { VS NEW } \\
\text { CHALLENGER }\end{array}$ & $\begin{array}{l}\text { INCUMBENT } \\
\text { VS NEW } \\
\text { CHALLENGER }\end{array}$ & $\begin{array}{l}\text { INCUMBENT } \\
\text { VS } \\
\text { INCUMBENT }\end{array}$ & OTHERS & TOTAL \\
\hline $\begin{array}{l}\text { Evaluation of party } \\
\text { leaders }\end{array}$ & $7.8 \%$ & $5.1 \%$ & $3.8 \%$ & $4.4 \%$ & $6.3 \%$ \\
\hline Party support & $37.2 \%$ & $26.6 \%$ & $40.4 \%$ & $16.7 \%$ & $29.8 \%$ \\
\hline Party policy & $10.9 \%$ & $9.5 \%$ & $7.7 \%$ & $9.9 \%$ & $12.1 \%$ \\
\hline Party vote total & $55.9 \%$ & $41.1 \%$ & $51.9 \%$ & $31.0 \%$ & $48.2 \%$ \\
\hline $\begin{array}{l}\text { Candidate } \\
\text { personality }\end{array}$ & $17.8 \%$ & $27.2 \%$ & $5.8 \%$ & $20.2 \%$ & $18.3 \%$ \\
\hline Candidate policy & $6.6 \%$ & $7.6 \%$ & $3.8 \%$ & $7.9 \%$ & $7.3 \%$ \\
\hline Personal vote total & $\underline{24.4 \%}$ & $34.8 \%$ & $9.6 \%$ & $\underline{28.1 \%}$ & $\underline{25.6 \%}$ \\
\hline Balance of seats & $2.4 \%$ & $7.6 \%$ & $0.0 \%$ & $6.4 \%$ & $4.0 \%$ \\
\hline $\begin{array}{l}\text { Profitability of the } \\
\text { workplace }\end{array}$ & $1.4 \%$ & $3.2 \%$ & $0.0 \%$ & $.5 \%$ & $1.1 \%$ \\
\hline Local interest & $5.7 \%$ & $6.3 \%$ & $5.8 \%$ & $8.9 \%$ & $6.4 \%$ \\
\hline Mobilization & $2.6 \%$ & $2.5 \%$ & $21.2 \%$ & $3.9 \%$ & $4.1 \%$ \\
\hline Others & $7.6 \%$ & $4.4 \%$ & $11.5 \%$ & $21.2 \%$ & $10.5 \%$ \\
\hline Total & 422 & 158 & 52 & 203 & 1139 \\
\hline
\end{tabular}

TABLE 6. Decision factors and the status of candidates.

factor was the evaluation of a party's leaders, party support, or a party's policy, and o, if otherwise.

Independent variables were as follows: whether or not voters were supporters of the LDP, the DPJ, Ishin, Mirai, and Minna ( 1 if partisan, o if not partisan), whether or not they were affiliated ( 1 if unaffiliated voters, $o$ if not), whether the electoral district had a pattern of two parties competing ( 1 if there were just two parties, o if not), whether the candidate status in the electoral district was an incumbent vs. a challenger ( 1 if so, o if not), whether electoral competition was fierce ( 1 if the successful candidate's share of the votes was more than twice that of the runner-up, o if not), and whether there was a candidate backed by a supporting party in the electoral district (if so 1 , if not o). The control variable was the population size ( 1 if the population was less than 50,000, 2 if less than 100,000, 3 if less than 150,000, and 4 if less than 200,000).

The results of this analysis are shown in TABLE 7. It is clear that the coefficient of DPJ partisan and unaffiliated voters is negative and statistically significant at the $1 \%$ level for the party vote. Moreover, electoral competition between the two parties had a negative effect on party votes. In addition, whether or not there was a candidate backed by a supporting 
$24 \mid$ JAPANESE POLITICAL SCIENCE REVIEW 3 (2016)

\begin{tabular}{lcccc}
\hline & B & STD. ERR & WALD & EXP(B) \\
\hline Population size & .076 & .054 & 1.970 & 1.079 \\
\hline LDP partisan & -.205 & .241 & .727 & .814 \\
DPJ partisan & $-.805^{* *}$ & .272 & 8.750 & .447 \\
Ishin partisan & .409 & .281 & 2.120 & 1.506 \\
Mirai partisan & .870 & .706 & 1.516 & 2.387 \\
Minna partisan & .013 & .325 & .002 & 1.013 \\
Unaffiliated voters & $-.487^{* *}$ & .214 & 5.172 & .614 \\
A candidate backed by a & $.793^{* *}$ & .223 & 12.596 & 2.210 \\
supporting party & & & & \\
\hline Two-party competition & $-.364^{*}$ & .156 & 5.409 & .695 \\
Electoral competition & -.032 & .132 & .061 & .968 \\
Candidate status & -.033 & .133 & .063 & .967 \\
\hline Constant & $-.428+$ & .228 & 3.514 & .652 \\
\hline
\end{tabular}

TABLE 7. The determinant of the party vote.

$\mathrm{N}=1139-2 L L: 1502.525$ NagelkerkeR2: 0.085

${ }^{* * *}: \mathrm{p}<0.005,{ }^{* *}: \mathrm{p}<0.01,{ }^{*}: \mathrm{p}<0.05,+: \mathrm{p}<0.10$

party is positive and statistically significant at the $1 \%$ level for the party vote.

\section{New Decision Factors Raised in the 2014 Lower House Election}

In the 2014 general election, which was held on 14 December, the LDP won 291 seats and maintained a two-thirds supermajority with the CGP. The DPJ and the JCP both increased their number of seats by about 10 seats, while Ishin and Mirai lost seats. On the whole, there were no changes in the electoral results. However, there were major changes in the decisions made by voters. ${ }^{3}$ TABLE 8 shows the decision factors in the 2014 general election. The personal vote decreased to $16.6 \%$ from $25.6 \%$ compared with the 2012 election. Nevertheless, the rate of the party vote remained at $48.2 \%$. Instead of the party vote, there was a new factor among voters: $12.8 \%$ of voters mentioned the balance of seats being a decisive factor.

3. The analysis in this section used individual-level panel data from the Japanese Election Study V (JESV), which was conducted via the Internet before and after the Lower House election of December 2014. These data include a quota sample for the strata of age, gender, and region, consisting of 2,786 respondents. 


\begin{tabular}{lcc}
\hline & & $(\%)$ \\
& 2012 & 2014 \\
\hline Evaluation of party leaders & 6.3 & 13.3 \\
Party support & 29.8 & 20.7 \\
Party policy & 12.1 & 14.2 \\
\hline Party vote total & 48.2 & 48.2 \\
\hline Candidate personality & 18.3 & 10.1 \\
Candidate policy & 7.3 & 6.5 \\
\hline Personal vote total & 25.6 & 16.6 \\
\hline Balance of seats & 4.0 & 12.8 \\
Profitability of the workplace & 1.1 & 1.0 \\
Local interest & 6.4 & 3.0 \\
Mobilization & 4.1 & 1.6 \\
Others & 10.6 & 16.8 \\
\hline
\end{tabular}

TABLE 8. Decision factors in the 2014 election.

A cross-tabulation of decision factors and party support is shown in TABLE 9. While the rate of the party vote by LDP and JCP supporters increased compared to the 2012 election, the rate of the party vote by the DPJ, the CGP, Ishin supporters, and unaffiliated voters decreased. The rate of the personal vote decreased among voters supporting any parties except for CGP supporters. The rate for the balance of seats as a deciding factor increased regardless of which party was supported.

In the 2014 general election in Japan, a new decision factor appeared that was neither party nor personal vote. MMM, a system that was thought would be able to introduce party-centered electoral politics, did not provide the expected results for Japanese electoral politics.

\section{Conclusion}

When the MMM system was introduced, many reformers expected to create party-centered Japanese electoral politics. They assumed that the MMM system would strengthen the incentives for the party vote due to the promotion of inter-party competition.

Nevertheless, the rate of party votes decreased in the 2012 election. It was clearly because the evaluation of the DPJ had been weakened due to administrative failure.

An important point to note here is that the cause of failure was not within the electoral system but rather within the DPJ itself. The electoral 


\begin{tabular}{|c|c|c|c|c|c|c|c|}
\hline \multicolumn{8}{|c|}{ PARTY SUPPORT } \\
\hline & \multirow[b]{2}{*}{ LDP } & \multirow[b]{2}{*}{ DPJ } & \multirow[b]{2}{*}{ CGP } & \multirow[b]{2}{*}{ ISHIN } & \multicolumn{3}{|c|}{ UNAFFILIATED } \\
\hline & & & & & JCP & VOTERS & TOTAL \\
\hline Party vote total & $62.0 \%$ & $35.1 \%$ & $48.2 \%$ & $49.9 \%$ & $62.7 \%$ & $26.5 \%$ & $48.2 \%$ \\
\hline Party vote total in 2012 & $55.9 \%$ & $41.1 \%$ & $51.9 \%$ & $63.5 \%$ & $61.5 \%$ & $31.0 \%$ & $48.2 \%$ \\
\hline Personal vote total & $14.1 \%$ & $21.5 \%$ & $20.4 \%$ & $16.2 \%$ & $9.2 \%$ & $19.6 \%$ & $16.6 \%$ \\
\hline $\begin{array}{l}\text { Personal vote total in } \\
2012\end{array}$ & $24.4 \%$ & $34.8 \%$ & $9.6 \%$ & $22.4 \%$ & $17.9 \%$ & $28.1 \%$ & $25.6 \%$ \\
\hline Balance of seats & $5.4 \%$ & $23.7 \%$ & $9.3 \%$ & $14.6 \%$ & $12.6 \%$ & $19.3 \%$ & $12.8 \%$ \\
\hline $\begin{array}{l}\text { Balance of seats in } \\
2012\end{array}$ & $2.4 \%$ & $7.6 \%$ & $0.0 \%$ & $0.0 \%$ & $5.1 \%$ & $6.4 \%$ & $4.0 \%$ \\
\hline
\end{tabular}

\begin{tabular}{llllllll}
\hline Total in 2014 & 735 & 228 & 54 & 246 & 174 & 466 & 1984 \\
\hline
\end{tabular}

TABLE 9. Decision factors and party support in the 2014 election.

system cannot control the performance of the political parties or the voters' evaluation of these performances. The DPJ did not fail administratively because of the MMM system; evaluation of political parties goes up and down in any type of electoral system. Hence, it seems that the MMM system is not the cause of a decrease in the party vote.

However, in the 2012 general election, the rate of party votes was $68.0 \%$ $(72.7 \%$ in 2009$)$ and the rate of personal votes was $8.5 \%(7.4 \%$ in 2009$)$ in proportional represention. Because of the inclusion of the single-member district system, MMM was the cause of a decrease in the party vote when the evaluation of political parties is low. Therefore, if we intend to promote a party-centered election, it is appropriate to adopt a proportional representation system without SMD.

\section{REFERENCES}

Cain, Bruce. E., John. A. Ferejohn, and Morris. P. Fiorina

1984 "Constituency Service Basis of the Personal Vote for us Representatives and British Members of Parliament." American Political Science Review 78: $110-25$.

Carey, John. M., and Matthew. S. Shugart

1995 "Incentives to Cultivate a Personal Vote: A Rank Ordering of Electoral Formulas." Electoral Studies 14(4): 417-39. 
Golden, Miriam, A.

2003 "Electoral Connections: The Effects of the Personal Vote on Political Patronage, Bureaucracy and Legislation in Postwar Italy." British Journal of Political Science 33(2): 189-212.

НАмамото, Shinsuke

2007 “The Decline of Personal Vote." Review of Electoral Studies 9:47-66.

НАмамото, Shinsuke, and Kuniaki Neмото

2011 "Kojin Chushin no Senkyo Senryaku to Sono Yukosei" [Campaigning for personal votes and its impact on electoral outcomes]. Nenpo Seijigaku 2: 70-97.

Hirano, Hiroshi

2008 "Tohyokōdō kara mita 'sisseibu-yukensha kankei' no henyo" [Core executive and the electorate: From the view of Japanese voting behavior]. Annals of the Japan Association for Comparative Politics 10: 19-38.

Hirano, Hiroshi, and Masaru KoHno

2011 Access Nihon Seiji [Access Japanese politics]. Tokyo: Nihon Hyoronsha.

Horiuchi, Yusaku, and Ryota Natori

2007 "Nidai Seitosei wo Sogai Suru Chiho Senkyo Seido" [The Impact of Subnational Electoral Systems on the Duvergerian Equilibrium: The Case of Japan]. Shakai Kagaku Kenkyū 58 (5/6): 21-32.

Krauss, Ellis, and Robert PEKKANEN

2004 "Explaining Party Adaptation to Electoral Reform: The Discreet Charm of the LDP?" Journal of Japanese Studies 30(1): 1-34.

MIYAKe, Ichiro

2001 Senkyo seido kaikaku to tohyo kodo [The electoral reform and voting behavior in Japan]. Tokyo: Bokutakusha.

Mori, Michiya, and Hidenori Tsutsumi

2010 "Minshuto Kohosha no Senkyo kyanpein to Kyoso Kankyo" [The electoral campaigns of DPJ candidates and the environment of electoral competition]. In Seikenkōtai senkyo no Seijigaku, ed. Hiroshi Shiratori, 37-64. Kyoto: Minerva Shobo.

Niwa, Isao

2010 “Jiminto Chiho Sochiki no Genzai." In Seikenkōtai senkyo no Seijigaku, ed. Hiroshi Shiratori, 186-210. Kyoto: Minerva Shobo.

PARK, Cheol Hee

2000 Daigishi no Tsukurare Kata [How Japan's Dietmen are made]. Tokyo: Bungeishunjū.

Primo, David M., and James M. SNyder, Jr.

2010 "Party Strength, the Personal Vote, and Government Spending." American Journal of Political Science 54(2): 354-70. 
REED, Steven R.

1994 "Democracy and the Personal Vote: A Cautionary Tale from Japan." Electoral Studies 13(1): 17-28.

2003 "The Effect of the PR Tier on SMD Nomination Strategies in Mixed Member System: Some Evidence from Japan.” Japanese Journal of Electoral Studies 18: 5-11.

Samuels, D. J.

1999 "Incentives to Cultivate a Party Vote in Candidate-centric Electoral Systems: Evidence from Brazil." Comparative Political Studies 32(4): 487518.

SHINADA, Yutaka

2011 "Preface." Nenpo Seijigaku 2: 3-6.

TANIGUCHI, Masaki

2004 Gendai Nihon no Senkyo Seiji: Senkyo Seido Kaikaku o Kensho Suru [Contemporary Japanese electoral politics: Investigating electoral reform]. Tokyo: University of Tokyo Press.

Tsutsumi, Hidenori

2009 "Senkyo Seido Kaikaku Ikō no Nihon ni okeru Kouhosha Kojin Tohyo" [Has the personal vote declined after electoral system reform in Japan?]. Kagawa Hoggaku 29(1): 58-90.

YAMADA, Masahiro

1997 "Nōsongata Senkyoku ni okeru Seikai Saihen oyobi Senkyo Seido Kaikaku no Eikyo" [Political realignment in rural districts]. In Seikai Saihen no Kenkyū: Shinsenkyo Seido ni yoru Sosenkyo [Study on political reorganization: General elections under the new electoral system], ed. Otake Hideo, 113-42. Tokyo: Yuhikaku. 